\title{
Does social identity affect business performance?
}

\author{
Marina Estrada-de la Cruz ${ }^{1}$, Antonio José Verdú-Jover, José María Gómez-Gras
}

Universidad Miguel Hernández de Elche, España

doi: $10.20420 /$ eni.2017.187

\begin{abstract}
The business founder's social identity is crucial to explaining his or her behaviour and attitude in business decision-making. Drawing on three types of entrepreneurial social identity identified by Fauchart and Gruber (2011), this study examines how social identities influence the entrepreneur's way of managing his/her firm and its consequences for business performance. Based on a survey of newly created firms, the results support the conclusion that effectuation channels the effects of specific identities - Darwinian and missionary- on business performance.
\end{abstract}

Keywords: University entrepreneurs, business performance, effectuation, social identity.

JEL classification: M130, L26, M10.

Reference source: Estrada-de la Cruz, M., Verdú-Jover, A.J., Gómez-Gras, J.M. (2017). Influence of the entrepreneur's social identity on business performance through effectuation. European Research on Management and Business Economics, https://doi.org/10.1016/j.iedeen.2017.11.003.

\section{Introduction}

Numerous studies have tried to answer questions about the different nuances relevant to identification and setting up of business opportunities (Shane, 2003). However, this studies ignore the crucial role of the differences in the entrepreneur's conceptions of this role, what the individual's subjectivity adds as he/she becomes founder of a firm (Hoang \& Gimeno, 2010). Introducing the concept of the founder's identity can incorporate the individual's thoughts, feelings, and beliefs as an entrepreneur (Rosenberg, 1979). Various studies argue that a key aspect of entrepreneurship research studies are the activities and behaviours undertaken. It is precisely Social Identity Theory that helps us to understand and explain the heterogeneous behaviours that founders pursue in the process of setting up a firm. For its analyses we will focus on Effectuation Theory developed by Sarasvathy (2001, 2008), the author differentiates between two types of reasoning in decision-making: causation and effectuation. Causation begins with a predetermined objective and a given set of means and seeks to identify the optimal alternative (the fastest, the cheapest, the most efficient, etc.) to achieve this goal. However, effectuation does not begin with a specific objective, but begins with a given set of means, among which we can find the identity of the entrepreneur, and allows the objectives to emerge. While the causal thinkers are like great generals looking to conquer fertile lands (Genghis Khan), the effectual thinkers are like explorers who establish trips to unexplored seas (Christopher Columbus) (Sarasvathy, 2001).

In this study, we attempt to answer two interrelated questions: It is possible that future management aspirations, goals and objectives shaping the founder's identity affect his or her decisions about the firm's growth? And, if so, can effectuation has a mediator effect in this relationship?

To achieve this goals, we next address the concept of the different social identities analysed

${ }^{1}$ Corresponding author: mestrada@umh.es 
by Fauchart and Gruber (2011) and how each identity can affect business performance. In addition, we propose Effectuation Theory, which consider the founder's own identity as a mean for the start-up process.

\section{Hypotheses}

In the business environment, the actions and behaviours of a founder or founding team in creation and subsequent development of a firm evolve together, since business activities are infused with meaning resulting from expression of individual identity. As various authors suggest, identities are the main sources of motivation for human behaviour.

We complement this focus with Effectuation Theory (Sarasvathy, 2001) and Social Identity Theory (Tajfel \& Turner, 1979), from the field of social psychology, to increase understanding of the reason for the substantial differences between creation processes and the results in different firms. This body of research provides a theoretical link to explain how social identification leads individuals to behave and act in ways that confirm their identities (Hogg \& Terry, 2000). Instead of evaluating businesspeople and their characteristics externally, research on business social identity focuses on how individuals identify and understand themselves as businesspeople (Alsos and others, 2016).

Our model is based on Fauchart and Gruber (2011), who identify three main types of business social identity: "Darwinian", "communitarian", and "missionary".

Darwinian identity describes the "classic businessperson", whose main goal is to establish a strong and successful business. Such entrepreneurs aim to create strong, profitable firms and seek business performance in the broadest sense.
Communitarian identity develops in individuals strongly motivated by a product or service to help a group of people who share related ideas.

Missionary identity is motivated by the desire to advance a greater cause, and its fundamental goal is to act responsibly. Missionary identities view their firms as platforms from which to pursue their social goals (Fauchart \& Gruber, 2011).

According to the foregoing, Social Identity Theory helps to understand and explain heterogeneity of business behaviour in the process of setting up a new business initiative and that initiative's orientation to its results.

Effectuation theory (Sarasvathy, 2001) provides a new framework for observing business phenomena, as well as for understanding how entrepreneurs think and act.

Sarasvathy (2008) suggests that effective businesspeople initiate the process based on who they are, what they know, and whom they know - that is, relative to their identity. The means that businesspeople use to set up the business are based on their identity, knowledge, and networks (Sarasvathy \& Dew, 2013). Specifically, when the goals are ambiguous, businesspeople tend to explain their actions based on their identities, not on their preferences or goals (Sarasvathy \& Dew, 2005). Differences in the entrepreneur's identity can also lead to differences in the actions chosen and thus to business performance relative to the competition.

Decision-making processes in the formative stage of business creation affect business development, including financial results.

Our theoretical model argues that Darwinian, communitarian, and missionary identities are positively oriented to business performance, 
even though the firm's founder has different goals. Given that, the identity of the individual is one of the means he uses when he is carrying out an effectual reasoning; it is possible that this variable can help us to understand the relationship between the different entrepreneurial social identities and business performance.

\section{Methodology}

The empirical part of our study uses data from the survey designed in the Global University Entrepreneurial Spirit Students' Survey (GUESSS) project for 2013/2014. GUESSS is a research project directed since 2003 by University of St. Gallen (Switzerland). Its goal is to study university students' entrepreneurial intentions worldwide. Our study received survey responses from 271 Spanish university students who had created their own firms.

\section{Measurement of the study variables}

Business performance: Measurement of the dependent variable was adapted from the scale validated by Eddleston, Kellermanns, and Sarathy (2008). This scale is composed of five questions about performance: sales growth, growth in market share, growth of profits, job creation, and innovative character.

Social identity: Based on a scale validated by Sieger and others (2016), we analysed the three types of identity described above (Darwinian identity, communitarian identity and missionary identity).

Effectuation: The scale to measure the variable effectuation was based on Chandler and others (2011).

All variables analysed were measured through a multi-item scale. The evaluations were captured through a Likert-type scale ranging from 1 to 7 points (where 1= Strongly disagree and $7=$ Strongly agree) .

\section{Analysis and results}

For the quantitative study, we performed two analyses to determine the differences between them. The first model included the direct relationship among the social identities (the variables described above) and the business result.

The results of the first model show that the identities classified as Darwinian and missionary have a positive and significant effect on business performance facilitating achievement of performance-related goals. Communitarian identity has a positive but non-significant relationship to business performance, suggesting an identity committed to the products the firm provides but not to the firm's overall results.

In order to evaluate the mediator effect, we follow the analysis proposed by Baron and Kenny (1986), which permits us to analyse only the independent variables that have a significant relationship to business performance. Figure 1 confirms fulfilment of the conditions required to apply this analysis.

The relationship between each identity Darwinian and missionary- and effectuation is significant, and the relationship between effectuation and business performance is positive and significant. Another condition of this analysis is that the effect of the dependent variable on the independent variable should cease to be significant when the latter is controlled by the mediating variable, a circumstance fulfilled by our model.

To provide more rigorous analysis, we analyse this effect using the criterion VAF, "Variance Account For". In our case, the mediation effect between Darwinian identity and performance is $72 \%$, and between missionary identity and business performance $63 \%$. In both cases, $20 \% \leq \mathrm{VAF} \leq 80 \%$, ultimately confirming 
partial, not total, mediation. The mediation model confirms that using effectuation partially mediates the relationship between the social identities defined as Darwinian and missionary, and business performance. The proposed model also shows good fit according to most of the indicators considered.

\section{Discussion and conclusions}

This study analyses both the founder's social identity as a factor that influences use of effectuation and the mediating effect of effectuation in business performance.

Regarding the relationships proposed in the first model, the data show a positive, significant relationship for Darwinian and missionary identities but a non-significant relationship for communitarian identity. Although these identities' objectives are very different, both consider the firm as a vehicle for achieving these objectives, making this relationship significant. However, the communitarian identity has a nonsignificant relationship with business performance, we could consider them as those founders who begin to enter into entrepreneurship gradually becoming aware in this process that the product designed for their own use cause a great interest to other users, that they consider as members of their community. They believe, therefore, that authenticity is the main asset they can bring to their company.

The second model confirms the partial mediating effect of effectuation. This finding enables us to conclude that, in pursuing their objectives, Darwinian and missionary identities start by using effectuation in decisions related to specific areas of the firm. Since a firm's decision-making process can produce different logics depending on the area involved, we could say that effectuation is partially entwined with the objectives and goals of Darwinian and missionary founders for the results of the firm. This finding enables us to identify the mechanisms for action through which a specific social identity achieves its effects. Both the management and creation of a new venture involves a large number of interrelated decisions, and links different crucial areas for business success. In this sense, the entrepreneur must analyse which is the most efficient means, considering causation and effectuation, to achieve the objectives based on their motivations and goals as a founder.

Therefore, we could say that the identity with which an entrepreneur wants to be recognized in society affects the logic used in the initial processes of the activity. We thus agree with Alsos and others (2016) that one should not initially assume that new firms are motivated only by obtaining profits. Founders have different motivations for setting up firms, and these motivations influence the founders' behaviour, creating complex structures in the logic used for decision making.

\section{References}

Alsos, G.A., Clausen, T.H., Hytti, U., \& Solvoll, S. (2016). Entrepreneurs' social identity and the preference of causal and effectual behaviours in startup processes. Entrepreneurship \& Regional Development, 28(3-4), 234-258.

Baron, R.M., \& Kenny, D.A. (1986). The moderatormediator variable distinction in social psychological research: Conceptual, strategic, and statistical considerations. Journal of Personality and Social Psychology, 51(6), 1173.

Chandler, G.N., DeTienne, D.R., McKelvie, A., \& Mumford, T.V. (2011). Causation and effectuation processes: A validation study. Journal of Business Venturing, 26(3), 375-390.

Eddleston, K.A., Kellermanns, F.W., \& Sarathy, R. (2008). Resource configuration in family firms: Linking resources, strategic planning and technological opportunities to performance. Journal of Management Studies, 45(1), 26-50.

Fauchart, E., \& Gruber, M. (2011). Darwinians, communitarians, and missionaries: The role of 
founder identity in entrepreneurship. Academy of Management Journal, 54(5), 935-957.

Hoang, H., \& Gimeno, J. (2010). Becoming a founder: How founder role identity affects entrepreneurial transitions and persistence in founding. Journal of Business Venturing, 25(1), 41-53.

Hogg, M.A., \& Terry, D.I. (2000). Social identity and self-categorization processes in organizational contexts. Academy of Management Review, 25(1), 121-140.

Rosenberg, M. (1979). Conceiving the Self. Basic, NY.

Sarasvathy, S.D. (2001). Causation and effectuation: Toward a theoretical shift from economic inevitability to entrepreneurial contingency. Academy of Management Review, 26(2), 243-263.

Sarasvathy, S.D. (2008). Effectuation: Elements of Entrepreneurial Expertise, New Horizons in Entrepreneurship. Cheltenham: Edward Elgar.
Sarasvathy, S.D., \& Dew, N. (2005). New market creation through transformation. Journal of Evolutionary Economics, 15(5), 533-565.

Sarasvathy, S.D., \& Dew, N. (2013). Without judgment: An empirically-based entrepreneurial theory of the firm. The Review of Austrian Economics, 26(3), 277-296.

Shane, S.A. (2003). A general theory of entrepreneurship: The individual-opportunity nexus. Edward Elgar Publishing.

Sieger, P., Gruber, M., Fauchart, E., \& Zellweger, T. (2016). Measuring the social identity of entrepreneurs: Scale development and international validation. Journal of Business Venturing, 31(5), 542572.

Tajfel, H., \& Turner, J.C. (1979). An integrative theory of intergroup conflict. The Social Psychology of Intergroup Relations, 33(47), 74.

Figure 1. Total mediation model

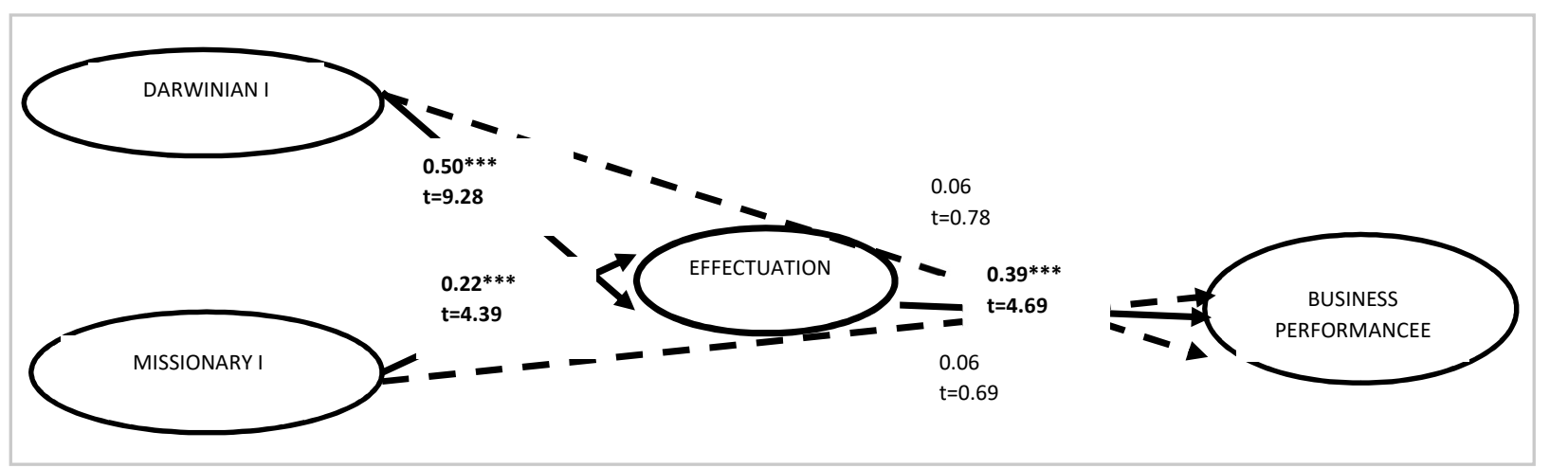

$\mathrm{R}^{2}($ Business performance $)=0.21 ; \mathrm{R}^{2}($ Effectuation $)=0.42$

$\mathrm{Q}^{2}($ Business performance $)=0.12 ; \mathrm{Q}^{2}($ Effectuation $)=0.21$;

Note: $\uparrow \mathrm{p}<0.10 ;{ }^{*} \mathrm{p}<0.05 ;{ }^{* *} \mathrm{p}<0.01 ; * * * \mathrm{p}<0.001$ 